\title{
The Effect of Entrepreneurship Education on Entrepreneurial Intention Mediated by Motivation and Attitude among Management Students, State University of Malang, Indonesia
}

\author{
Angga Martha Mahendra ${ }^{1}$, Ery Tri Djatmika ${ }^{2}$ \& Agus Hermawan ${ }^{2}$ \\ ${ }^{1}$ Graduate School Student, Universitas Negeri Malang, Indonesia \\ ${ }^{2}$ Faculty of Economics, Universitas Negeri Malang, Indonesia \\ Correspondence: Ery Tri Djatmika, Universitas Negeri Malang, Indonesia. E-mail: ery.tri.fe@um.ac.id
}

Received: March 21, 2017

Accepted: April 28, $2017 \quad$ Online Published: August 27, 2017

doi:10.5539/ies.v10n9p61

URL: https://doi.org/10.5539/ies.v10n9p61

\begin{abstract}
This research investigates the effect of entrepreneurship education on entrepreneurial intention among college students enrolling in the Department of Management, Faculty of Economics, State University of Malang. The research employed descriptive correlational design, and a number of 230 students are taken proportionate randomly as sample from 540 students enrolled in three study programs. Path analysis utilizing LISREL 8.50 for windows is used to examine relationships among variables. Research finding revealed that entrepreneurial intention is indirectly affected by entrepreneurship education, meaning that students' entrepreneurial motivation and attitude are two important mediating variables.
\end{abstract}

Keywords: entrepreneurship education, entrepreneurial motivation, entrepreneurial attitude, entrepreneurial intention

\section{Introduction}

Unemployment occurred in Indonesia in 2016 reached 5.6\% (source: Indonesia Statistical Bureau, https://www.bps.go.id/linkTabelStatis/view/id/981) has impact on social and economic issues. This unemployment occurred for graduates either from college or vocational senior high schools. Factor that influences of unemployment is high number of job seekers among those graduates as results of students mental thought and mind setting to be employees either in private or public sectors. According the speech of President of Republic of Indonesia, Joko Widodo on the opening of the Summit of Indonesia Young Entrepreneur Association (Tempo, 2016), pointed out that ironically, increasing number of unemployed was dominated by the educated unemployed.

Entrepreneurship is considered an effective approach to overcome these problems, and it is expected that there should be at least $2 \%$ total number of entrepreneurs of the whole population (McClelland and David, 2007). To overcome and attain the amount percentage of entrepreneurial ideal and reduce number of unemployed in Indonesia, the government implemented a policy in the field of entrepreneurship education set up from primary schools up to college, with purpose to grow entrepreneurial intention among them which in turn is able to create entrepreneurs oriented creating jobs or not to look for work. The intention is an influential variable in initiating venture formation and has substantial impact on the achievement of business (Johnmark \& Munene, 2016).

The achievement of these objectives is expected to initiate new businesses from college graduates who have a spirit of entrepreneurship and entrepreneurial intentions, so the impact on reduction of unemployment rate in Indonesia. The role of entrepreneurship education is projected to provide theoretical foundation of entrepreneurship concepts, forming mindset, attitude, and behaviour of an entrepreneur. Entrepreneurship education is a body of knowledge has two dimensions, venture start-ups and venture growth as well as having its own objects the ability to create productive activities (Suryana, 2013).

The importance of entrepreneurship education at college is emphasised through a presidential speech Joko Widodo in the Summit of Indonesia Young Entrepreneur Association in Bandung. He mentioned that as the national consciousness, Indonesia needs smart entrepreneurs and surely there must be synergy among universities (Tempo, May 23, 2016). Faculty of Economics, State University of Malang offers Entrepreneurship 
Education course and provide learning that refers to cognitive, psychomotor, and affective domains. The course was delivered by using multimedia and two-way teaching interaction to attract students' attention, and students' involvement in project activities, in the intention is to grow students' entrepreneurial motivation and attitudes. The implementation of entrepreneurship learning process is also designed to develop psychomotor domain by giving assignments to students to create innovative new products and to initiate new business activities. These activities are expected able to motivate students' entrepreneurship.

Entrepreneurial motivation is an energy that encourages individual doing activities leading to attainment of the needs, contributing satisfaction, and reducing imbalance by opening an enterprise or a business (Zimmerer et al., 2008). It is expected that students who have obtained entrepreneurship education to exhibit high motivation. Likewise, entrepreneurial attitude is an individual's readiness to respond consistently to characteristics owned by an entrepreneur (Meredith, 2005). Students' entrepreneurial attitude can be affected by entrepreneurship education that encourages them doing something productive that was the intention in accordance with enhancement of their entrepreneurship abilities. Therefore, the entrepreneurial attitude is an essential character in influencing an individual mindset and behavior to be able to show their entrepreneurial intention.

Entrepreneurial intention is a desire doing productive activities effectively that directing individuals to utilize and implement relevant concepts of new business (Krueger et al., 2000). Students' awareness is able to be influenced and developed by external factors in terms of entrepreneurship education that underlie the emergence of their entrepreneurial intentions. This perspective can be seen from the Theory of Planned Behavior as mentioned by Ajzen (2005) stating that the intention was affected by a person's behavior. The entrepreneurial intention is not inherited, but it can be trained and developed through education. It is in line with Athayde (2009) point of view that entrepreneurial attributes can be positively shaped by the educational programs that build students awareness about entrepreneurship as a career option.

Research on the area of entrepreneurship is essential in helping to achieve the ideals of Indonesian people to overcome problem of unemployment with emerging new jobs, and changing students' thinking from job seekers into job creators. So, it will have positive impact on the nation and next generation movement. Starting entrepreneurship education is a first step for driving from within to perform self-employment by creating new businesses or new jobs. The implementation of entrepreneurship education has to incorporate: (1) content that deepening and enriching scope of materials learned through group discussion, (2) context that emphasizing in networking and learning by doing in group setting, (3) technique that enabling students work collaboratively and creatively, and (4) individual characteristics, capabilities, and potentials as a unity (Shabani, 2013).

Previous studies have been conducted by scholars in the area of entrepreneurship education. It is a study that aims to stimulating students' intentions as well as challenging students to establish new businesses as future career choice. Research findings (Kuttim et al., 2014; Kim-Soon et al., 2016) showed that participation in entrepreneurship education has a positive effect on students' entrepreneurial intentions. There is a significant relationship between entrepreneurial intention and entrepreneurship education (Hussain \& Norashidah, 2015; Lorz, 2011; Hattab, 2015; Ibrahim et al., 2015), through students' involvement in experiential and existential lifelong learning practices (Robinson et al., 2016), and through developing meaning of action, reflections, and experience (Hagg \& Kurczewska, 2016). Moreover, the role of entrepreneurship education delivered to students is able to improve their achievement orientation, personal control, and self-esteem (Basardien et al., 2016).

Entrepreneurial motivation is a self-encouragement as contribution of either internal or external factors that enable to grow entrepreneurial intentions. Study conducted by Guerrero et al. (2008) revealed that intrinsic motivation and normative environment have positive impact on entrepreneurial intentions. Likewise, personal capacity and regulatory environment have positive impact on the feasibility of starting new businesses. This is relevant with the theory of planned behavior as mentioned by Ajzen (1991, 2005), where an entrepreneur is a person who is attempting with resolution and drive of his/her business to grow.

Entrepreneurial attitude is considered as one of antecedents to achieving entrepreneurial intention as supported in previous studies (Linan \& Chen, 2009; Ali et al., 2011; Weerakoon \& Gunatissa, 2014; Wach \& Wajciechowski, 2016). Most of previous research positioned Ajzen's Theory of Planned Behavior (TPB) as a foundation in developing conceptual framework, and empirically the use of TPB has positive support. Likewise, previous research findings (Fitzsimmons \& Douglas, 2005; Susetyo \& Lestari, 2014; Asmara et al., 2016; Firmansyah et al., 2016) revealed that entrepreneurial attitude and ability of a person found to be connected with entrepreneurial intentions of individual. Besides, cross-cultural differences were also found as determinant of differences in entrepreneurial attitudes and intentions.

Entrepreneurship education is a process of instilling, growing, and forming students' entrepreneurial competence 
through improving knowledge obtained from and their experience and practical engagement in lectures. Knowledge learned and skills trained and developed during a semester taking the course is expected enable boosting students' motivation and attitude from inside becoming an entrepreneur (Raposo \& do Paco, 2011). Practicality of entrepreneurship education is able to improve students' entrepreneurial competencies developed during taking the course and provide a positive impact on students' entrepreneurial motivation (Khalili et al., 2014; Farhangmehr et al., 2016; Jakubiak \& Buchta, 2016). Previous research (Prodjosoesilo, 2005; Alain et al., 2006) revealed that there are relationships among students' entrepreneurial motivation and attitudes, entrepreneurship learning process, and students' concern in entrepreneurship education. Lee and Wong (2003) also uncovered that entrepreneurship education in higher education has a direct impact on forming students' attitudes in taking risks for the establishment of new businesses. In spite of this, research finding (Rengiah \& Sentosa, 2016) revealed that entrepreneurial attitude mediates the relationship between entrepreneurship education and entrepreneurial intention.

Based on previous studies above, this study hypothetically examines the relationship among variables as conceptualized in Figure 1.

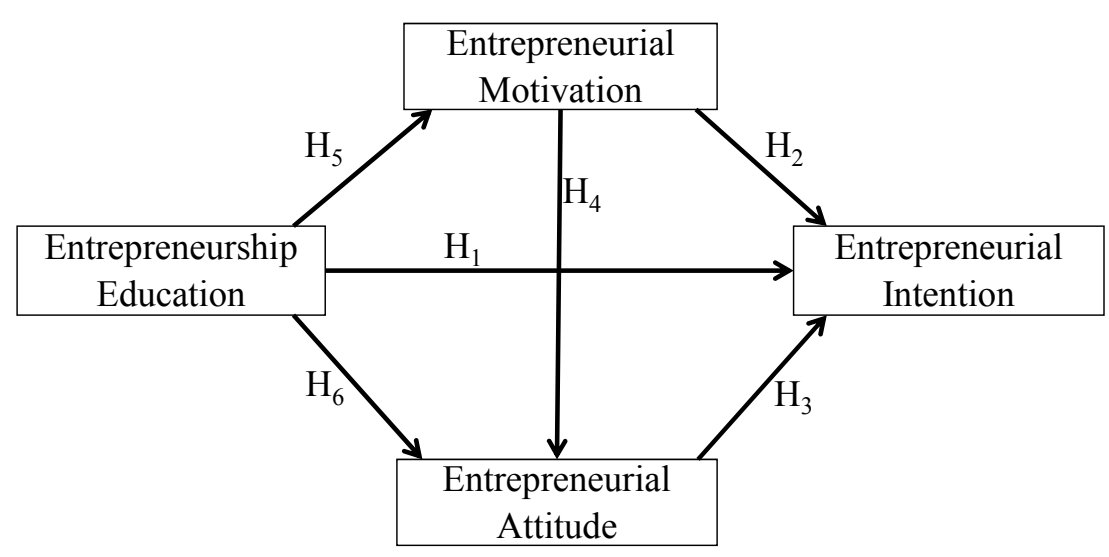

Figure 1. Conceptual framework

There are six hypothesis examined in this study. These include a relationship between entrepreneurship education and entrepreneurial intention $\left(\mathrm{H}_{1}\right)$, a relationship between entrepreneurial motivation and entrepreneurial intention $\left(\mathrm{H}_{2}\right)$, a relationship between entrepreneurial attitude and entrepreneurial intention $\left(\mathrm{H}_{3}\right)$, a relationship between entrepreneurial motivation and entrepreneurial attitude $\left(\mathrm{H}_{4}\right)$, a relationship between entrepreneurship education and entrepreneurial motivation $\left(\mathrm{H}_{5}\right)$, and a relationship between entrepreneurship education and entrepreneurial attitude $\left(\mathrm{H}_{6}\right)$.

\section{Method}

This research employed descriptive correlational design, and path analysis was used to examine relationship among variables hypothesized. Population was students enrolled in the Department of Management, Faculty of Economics, State University of Malang who have already taken Entrepreneurship Education course in academic year 2014/2015. They involved 540 students from three study programs, and sample taken by using proportionate random sampling technique. A number of 230 students were obtained as respondents by implementing Slovin's formula (see Israel, 1992; Tejada \& Punzalan, 2012). Population and Sample of this research were composed in Table 1.

Table 1. Research population and sample

\begin{tabular}{llcc}
\hline No. & Study Programs in the Department of Management & Population & Sample \\
\hline 1. & Distributive Education & 87 Students & 37 Students \\
2. & Office Administration Education & 174 Students & 74 Students \\
3. & Management & 279 Students & 119 Students \\
& Total & 540 Students & 230 Students \\
\hline
\end{tabular}


Research instruments for measuring variables were adapted and modified from measurements that have been exercised in previous studies. The instruments used Likert scale ranging from 1 (strongly disagree) up to 5 (strongly agree) as responses from respondents. Sample of item for instrument used to measure entrepreneurial intention is "I have a strong belief to become an entrepreneur" (Linan and Chen, 2006; Ali et al., 2011), and overall Cronbach's alpha for this instrument reached 0.882 meaning that the instrument is reliable. Sample of item for instrument used to measure entrepreneurial attitude is "I always keep learning to increase innovation and creativity in entrepreneurship" (Robinson et al., 1991), and overall Cronbach's alpha for this instrument reached 0.951 meaning that the instrument is reliable. Sample of item for instrument used to measure entrepreneurial motivation is "I have the inner urge to self-employment" (Grunhagen \& Berg, 2012), and overall Cronbach's alpha for this instrument reached 0.861 meaning that the instrument is reliable. Sampel of item for instrument used to measure entrepreneurship education is "I believe that I received entrepreneurial knowledge that is useful for my future life" (Hansemark, 1998; Lorz, 2011), and overall Cronbach's alpha for this instrument reached 0.885 meaning that the instrument is reliable.

From 230 targeted respondents, there were 224 complete returned responses from respondents and analyzed for this research ( $97.39 \%$ rate of response), and only 6 responses were categorized into inappropriate and dropped. Furthermore, to examine hypothetical relationship among variables as figured out in conceptual framework, the data were analyzed by using LISREL 8.5 software for windows.

\section{Findings and Discussion}

The standardized solution result of path analysis utilizing LISREL 8.5 for windows is presented in Table 2 .

Table 2. Relationship among variables (standardized solution)

\begin{tabular}{|c|c|c|c|c|c|}
\hline No. & Variables & $\begin{array}{c}\text { Entrepreneurship } \\
\text { Education } \\
\text { (Gamma) }\end{array}$ & $\begin{array}{c}\text { Entrepreneurial } \\
\text { Motivation } \\
\text { (Beta) }\end{array}$ & $\begin{array}{c}\text { Entrepreneurial } \\
\text { Attitude } \\
\text { (Beta) }\end{array}$ & $\begin{array}{c}\text { Entrepreneurial } \\
\text { Intention } \\
\text { (Beta) }\end{array}$ \\
\hline 1. & $\begin{array}{l}\text { Entrepreneurial } \\
\text { Motivation }\end{array}$ & $0.49^{*}$ & --- & --- & --- \\
\hline 2. & $\begin{array}{l}\text { Entrepreneurial } \\
\text { Attitude }\end{array}$ & $0.17^{*}$ & $0.76^{*}$ & --- & --- \\
\hline 3. & $\begin{array}{l}\text { Entrepreneurial } \\
\text { Intention }\end{array}$ & $\begin{array}{c}0.00 \\
\text { (Non Sig.) }\end{array}$ & $0.19^{*}$ & $0.70^{*}$ & --- \\
\hline
\end{tabular}

${ }^{*}$ Significant at $0.05 ; \mathrm{R}^{2}=0.76$.

Relationships of all variables show significant effects, but the relationship between entrepreneurship education and entrepreneurial intention showing not significant as come out in broken line in Figure 2.

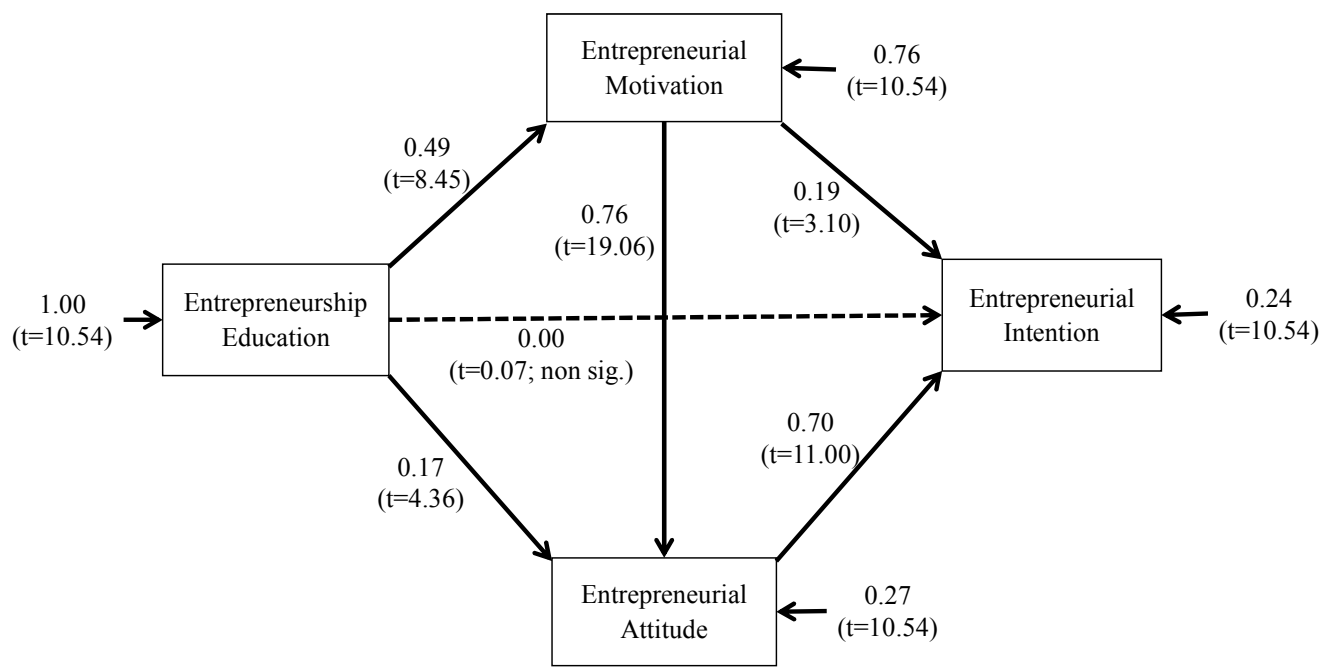

Chi-Square $=0.00, \mathrm{df}=0, \mathrm{P}-$ Value $=1.00000, \mathrm{RMSEA}=0.000$

Figure 2. Research finding, relationship among variables 
Here, it can be seen that the goodness of fit statistics of relationship among variables is absolutely meet the criteria where the value of Chi-Square $=0.00, \mathrm{df}=0, \mathrm{P}-\mathrm{Value}=1.00$, and RMSEA $=0.00$. This means that the model is suitable to be used to examine the research hypothesis.

Results of hypothesis testing based on empirical finding of relationships among variables are presented in Table 3.

Table 3. Hypothesis testing

\begin{tabular}{llll}
\hline No. & Hypothesis & Empirical Results \\
\hline 1. & There is a relationship between entrepreneurship education and entrepreneurial intention $\left(\mathrm{H}_{1}\right)$ & Not Supported \\
2. & There is a relationship between entrepreneurial motivation and entrepreneurial intention $\left(\mathrm{H}_{2}\right)$ & Supported \\
3. & There is a relationship between entrepreneurial attitude and entrepreneurial intention $\left(\mathrm{H}_{3}\right)$ & Supported \\
4. & There is a relationship between entrepreneurial motivation and entrepreneurial attitude $\left(\mathrm{H}_{4}\right)$ & Supported \\
5. & There is a relationship between entrepreneurship education and entrepreneurial motivation $\left(\mathrm{H}_{5}\right)$ & Supported & Supported \\
6. & There is a relationship between entrepreneurship education and entrepreneurial attitude $\left(\mathrm{H}_{6}\right)$ &
\end{tabular}

A most important research finding revealed from this research that there is no direct relationship between entrepreneurship education and entrepreneurial intention among students enrolled in the Department of Management, Faculty of Economics, State University of Malang. The entrepreneurship education takes part as antecedent variable that contributing to affect directly on both entrepreneurial motivation and entrepreneurial attitude, and its impact indirectly on entrepreneurial intention. Accordingly, the position of both entrepreneurial motivation and entrepreneurial attitude is mediating variables that mediate between entrepreneurship education and entrepreneurial intention. This empirical research supports the finding revealed by Rengiah and Sentosa (2016).

The purpose of carrying out entrepreneurship education is to increase students' entrepreneurial capacities in terms of knowledge, skills, attitude or affection, including motivational aspects. In this research, effective entrepreneurship teaching received by students is able to stimulate the growing of motivation and attitude as essential learning features for accomplishing entrepreneurial assignments. This research finding supports the works of Khalili et al. (2014), Farhangmehr et al. (2016), and Jakubiak and Buchta (2016). It is also found that the higher students' entrepreneurial motivation make possible for them to reach the higher students' entrepreneurial attitude. This finding supports the study of Prodjosoesilo (2005), and Alain et al. (2006). Moreover, both variable, entrepreneurial motivation and entrepreneurial attitude found to be directly influence the entrepreneurial intention. This finding supports the works of Guerrero et al. (2008), Fitzsimmons and Douglas (2005), Susetyo and Lestari (2014), Asmara et al. (2016), Firmansyah et al. (2016).

The entrepreneurial intention is considered as a starting stage for students before they carry out of establishing new ventures and taking role as new starters. As the need of an economy, there is a demand to increase a number of entrepreneurs in a society not only because of their contribution of providing jobs, but also their positive impact on regional gross domestic products. Then, the question is how students' entrepreneurial intention able to be extensively developed, and how to make entrepreneurial intention be one of university students' characteristics. It is realized that the developing entrepreneurial intention is a valuable perspective to be included in the process of teaching and learning, and also level of entrepreneurial intention as one of learning outcome achievement indicators to measure the propensity among students to take part as new young entrepreneurs after graduates. Accordingly, the main endeavor is to promote developing entrepreneurial intention to be widely familiarized and acceptable among university students.

There should be a movement to provide entrepreneurship education for university students that indirectly foster their intention to perform new businesses. Research finding revealed that entrepreneurship education has substantial role for developing students' entrepreneurial motivation and attitude. Although not directly affected on entrepreneurial intention, the main effort of providing entrepreneurship education with putting all aspects of students' capacities building including knowledge, skills, and practical capabilities as end learning outcomes is a valuable means to shape upright students' entrepreneurial motivation and attitude. This is relevant with study of Gina et al. (2014) and Yusoff et al. (2015). Moreover, with the incremental growing of entrepreneurial motivation and attitude, it is expected that there will be also the escalating of students' intention to start running new business ventures.

In the era of digitally world, main characteristic of current university students is related to the use of information 
technology in almost their whole live. They are very connected to and are not able to be separated from information technology devices. Accordingly, teaching strategy in delivering entrepreneurship education has to include methods that facilitate the use of technology to be incorporated in learning process. Instructional approach of entrepreneurship education has to be designed creatively and innovatively by using multimode of instruction that could attract students to engage entirely and enable them enhancing their entrepreneurial motivation and attitude. Besides, it is able to stimulating them to devote their minds to create a genuine idea regarding opportunity for taking action to initiate new business.

Teaching entrepreneurship education is not only a matter of delivering content of materials as offered in curriculum syllabus, but also how to activate students thoroughly to involve to working collaboratively among them and with potential partners such as business societies around them. Teaching can be designed to stimulate students and provide opportunity form them to generate practical business simulation, constructing and modeling business canvas, conducting benefit cost analysis, conducting feasibility study, prospecting new ventures or business potentials, inventing and elaborating ideas, designing business networking, and many other stimulating learning activities. In a few words, entrepreneurship education has influential role for triggering intrinsic motive and attitude among university students.

\section{Conclusion}

Main concern of this study is entrepreneurial intention among students' enrolled in the Department of Management, State University of Malang. Students involved in this study have taken Entrepreneurship Education course during one semester. The entrepreneurial intention is considered as essential variable contributing to students' propensity to initiate and create new business ventures as their future alternative career path. The current study revealed that the entrepreneurial intention among students is not directly affected by entrepreneurship education. It is found that the contribution of entrepreneurship education is able to enhance both students' entrepreneurial motivation and attitude. Both the motivation and attitude altogether take a role as mediation variables between entrepreneurship education and entrepreneurial intention. The higher motivation and attitude affected by entrepreneurship education, the higher the intention to establish new business among students under this study.

The important point of entrepreneurship education is its function to facilitate in developing entrepreneurial students' character, including providing opportunity to experiencing and practicing real contextual learning for developing their entrepreneurial capacities. The position of entrepreneurship education is a central of instructional activity that influencing students to develop their capabilities through collaborative learning, emphasizing innovation, creativity and networking. This will be beneficial for students to be able to anticipate and predict future business possibilities. It is suggested that the implementation of entrepreneurship education course has to be delivered interactively accommodating students involvement in entire learning process. In addition to entrepreneurial motivation and attitude, for future research there are other valuable psychological characteristics that also have to be internally developed among students taking entrepreneurship education considered also contribute to the improvement of entrepreneurial intention. Such research needs to explore whether other psychological characteristics variables actually affect students entrepreneurial intention.

\section{References}

Ajzen, I. (1991). The Theory of Planned Behavior. Organizational Behavior and Human Decision Processes, 50(2), 179-211. https://doi.org/10.1016/0749-5978(91)90020-T

Ajzen, I. (2005). Attitude, Personality and Behavior (2nd ed.). Poland, EU: Open University Press.

Alain, F., Benoit, G., \& Narjisse, L.-C. (2014). Effect and Counter-Effect of Entrepreneurship Education and Social Context on Student's Intentions. Estudios de Economia Aplicada, 24(2), 509-523.

Ali, A., Topping, K. J., \& Tariq, R. H. (2011). Entrepreneurial Attitudes among Potential Entrepreneurs. Pakistan Journal of Commerce and Social Sciences, 5(1), 12-46.

Asmara, H. W., Djatmika, E. T., \& Indrawati, A. (2016). The Effect of Need for Achievement and Risk Taking Propensity on Entrepreneurial Intention through Entrepreneurial Attitude. Journal of Business and Management, 18(6), 117-126. http://doi.org/10.9790/487X-180601117126.

Athayde, R. (2009). Measuring Entreprise Potential in Young People. Entrepreneurship Theory \& Practice, 33(2), 481-500. https://doi.org/10.1111/j.1540-6520.2009.00300.x

Basardien, F., Friedrich, C., \& Twum-Darko, M. (2016). Evidence-Based Practices of Promoting Entrepreneurship Education in Higher Education Institutions in Africa. Journal of Economics and 
Behavioral Studies, 8(5), 68-81.

Cameron, R., Ginsburg, H., Westhoff, M., \& Mendez, R. V. (2012). Ajzen's Theory of Planned Behavior and Social Media Use by College Students. American Journal of Psychological Research, 8, 1-20.

Farhangmehr, M., Goncalves, P., \& Sarmento, M. (2016). Predicting Entrepreneurial Motivation among University Students. Education + Training, 58(7/8), 861-881. https://doi.org/10.1108/ET-01-2016-0019

Firmansyah, A. H., Djatmika, E. T., \& Hermawan, A. (2016). The Effect of Adversity Quotient and Entrepreneurial Self-Efficacy on Entrepreneurial Intention through Entrepreneurial Attitude. Journal of Business and Management, 18(5), 45-55. http://doi.org/ 10.9790/487X-1805014555.

Fitzsimmons, J. R., \& Douglas, E. J. (2005). Entrepreneurial Attitudes and Entrepreneurial Intentions: A Cross-Cultural Study of Potential Entrepreneurs in India, China, Thailand and Australia. Babson-Kauffman Entrepreneurial Research Conference. Wellesley, MA. June, 2005.

Gina, A., Simatupang, T. M., \& Gustomo, A. (2014). A Systematic Framework for Entrepreneurship Education within a University Context. International Education Studies, $7(12), \quad 1-19$. https://doi.org/10.5539/ies.v7n12p1

Grunhagen, M., \& Berg, H. (2012). Sosial Entrepreneurship in the Market System. In C. K. Volkmann, K. O. Tokarski, \& K. Ernst (Eds.), Social Entrepreneurship and Social Business: an Introduction and Discussion with Case Studies. Wiesbaden: Springer-Gabler. https://doi.org/10.1007/978-3-8349-7093-0_11

Guerrero, M., Rialp, J., \& Urbano, D. (2008). The Impact of Desirability and Feasibility on Entrepreneurial Intentions: a Structural Equation Model. International Entrepreneurship and Management Journal, 4, 35-50. https://doi.org/10.1007/s11365-006-0032-X

Hägg, G., \& Kurczewska, A. (2016). Connecting the Dots: A discussion on Key Concepts in Contemporary Entrepreneurship Education. Education $+\quad$ Training, 58(7/8), $700-714$. https://doi.org/10.1108/ET-12-2015-0115

Hansemark, O. C. (1998). The Effects of an Entrepreneurship Programme on Need for Achievement and Locus of Control of Reinforcement. International Journal of Entrepreneurial Behavior \& Research, 4(1), 28-50. https://doi.org/10.1108/13552559810203957

Hattab, H. W. (2015). The Impact of Entrepreneurship Education on Entrepreneurial Intentions of University Students in Egypt. The Journal of Entrepreneurship, 23(1), 1-18. https://doi.org/10.1177/0971355713513346

Hussain, A., \& Norashidah. (2015). Impact of Entrepreneurial Education on Entreprenerial Intention of Pakistani Students. Journal of Entrepreneurship and Business Innovation, 2(1), 43-53. https://doi.org/10.5296/jebi.v2i1.7534

Ibrahim, W. N. A., Bakar, A. R., Asimiran, S., Mohamed, S., \& Zakaria, N. S. (2015). Impact of Entrepreneurship Education on the Entrepreneurial Intentions of Students in Technical and Vocational Education and Training Institutions (TVET) in Malaysia. International Education Studies, 8(12), 141-156. https://doi.org/10.5539/ies.v8n12p141

Israel, G. D. (1992). Determining Sample Size. Paper. Florida Cooperative Extension Service. University of Florida. Fact Sheet PEOD-6. November 1992.

Jakubiak, M., \& Buchta, K. (2016). Determinants of Entrepreneurial Attitudes in Relation to Students of $\begin{array}{llllll}\text { Economics and Non-Economics. Studia } i \quad \text { Materialy, } & \text { 2(1), }\end{array}$ http://doi.org/10.7172/1733-9758.2016.21.2

Johnmark, D. R., \& Munene, J. (2016). Discrimination in Predicting Entrepreneurial Intentions of the Disabled Students in Nigeria. International Journal of Managerial Studies and Research, 4(1), 1-13. https://doi.org/10.20431/2349-0349.0401001

Khalili, B., Tojari, F., \& Rezaei, M. (2014). The Impact of Entrepreneurship Training Course on the Development of Entrepreneurial Features. European of Academic Research, 2(9), 11942-11953.

Kim-Sun, N., Ahmad, A. R., \& Ibrahim, N. N. (2016). Theory of Planned Behavior: Undergraduates' Entrepreneurial Motivation and Entrepreneurship Career Intention at a Public University. Journal of Entrepreneurship: Research \& Practice, 1-14.

Krueger Jr., N. F., Reilly, M. D., \& Carsrud, A. L. (2000). Competing Models of Entrepreneurial Intentions. 
Journal of Business Venturing, 15(5-6), 411-432. https://doi.org/10.1016/S0883-9026(98)00033-0

Kuttim, M., Kallaste, M., Venesaar, U., \& Kiis, A. (2014). Entrepreneurship Education at University Level and Students Entreprenerial Intentions. Journal Procedia - Social and Behavioral Sciences, 110, 658-668. https://doi.org/10.1016/j.sbspro.2013.12.910.

Lee, L., \& Wong, P.-K. (2003). Attitude towards Entrepreneurship Education and New Venture Creation. Journal of Enterprising Culture, 11(4), 339-357. https://doi.org/10.1142/S0218495803000111

Linan, F., \& Chen, Y.-W. (2009). Development and Cross-Cultural Application of a Spesific Instrument to Measure Entrepreneurial Intentions. Entrepreneurship Theory and Practice, 33(3), 593-617. https://doi.org/10.1111/j.1540-6520.2009.00318.x

Lorz, M. (2011). The impact of Entrepreneurship Education on Entrepreneurial Intention (Unpublished dissertation). The University of St. Gallen, School of Management, Economics, Law, Social Sciences and International Affairs, Germany.

McCelland, D. C. (2007). Memacu Masyarakat Berprestasi: Mempercepat Laju Pertumbuhan Ekonomi melahi Peningkatan Motif Berprestasi. Terjemahan. Jakarta: Intermedia.

Meredith, G. G. (2005). Kewirausahaan: Teori dan Praktek (terjemahan). Jakarta: PT Pustaka Binaman Passindo.

Prodjosoesilo, S. (2005). Analisis Hubungan Kausal Motivasi, Sikap dan Proses Belajar Mengajar terhadap Minat Berwirausaha para Mahasiswa pada Universitas Negeri di Kota Malang (Unpublished dissertation). Malang: Graduate School, Universitas Negeri Malang.

Raposo, M., \& do Paco, A. (2011). Entrepreneurship education: Relationship between education and entrepreneurial activity. Psicothema, 23(3), 453-457.

Rengiah, P., \& Sentosa, I. (2016). The Effectiveness of Entrepreneurship Education in Developing Entrepreneurial Intentions among Malaysian University Students: (a Research Findings on the Structural Equation Modeling). European Journal of Business and Social Sciences, 5(2), 30-43. https://doi.org/10.21859/eulawrev-08063

Robinson, P. B., Stimpson, D. V., Huefner, J. C., \& Hunt, H. K. (1991). An Attitude Approach to Prediction of Entrepreneurship. Entrepreneurship Theory and Practice, 15(4), 13-31.

Robinson, S., Neergaard, H., Tanggaard, L., \& Krueger, N. F. (2016). New Horizons in Entrepreneurship Education: from Teacher-Led to Student-Centered Learning. Education + Training, 58(7/8), 661-683. https://doi.org/10.1108/ET-03-2016-0048

Shabani, S. (2013). Entrepreneurship Education: a New Conceptual Model in Developing Countries. Australian Journal of Basic and Applied Sciences, 7(8), 781-786.

Suryana. (2013). Kewirausahaan - Kiat dan Proses Menuju Sukses. Jakarta: Salemba Empat.

Susetyo, D., \& Lestari, P. S. (2014). Developing Entrepreneurial Intention Model of University Students (An Empirical Study on University Students in Semarang, Indonesia). International Journal of Engineering and Management Sciences, 5(3), 184-196.

Tejada, J. J., \& Punzalan, J. R. B. (2012). On the Misuse of Slovin's Formula. The Phillipine Statistician, 61(1), 129-136.

Wach, K., \& Wajciechowski, L. (2016). Entrepreneurial Intentions of Students in Poland in the View of Ajzen's Theory of Planned Behaviour. Entrepreneurial Business and Economics Review, 4(1), 83-94. https://doi.org/10.15678/EBER.2016.040106

Weerakoon, W. M. P. G. C., \& Gunatissa, H. H. A. J. (2014). Antecedents of Entrepreneurial Intention (with Reference to Undergraduates of UWU, Sri Lanka). International Journal of Scientific and Research Publications, 4(11), 1-6.

Yusoff, M. N. H. B., Zainol, F. A., \& Ibrahim, M. D. B. (2015). Entrepreneurship Education in Malaysia's Public Institutions of Higher Learning - A Review of the Current Practices. International Education Studies, 8(1), 17-28. https://doi.org/10.5539/ies.v8n1p17

Zimmerer, T. W., Scarborough, N. M., \& Wilson, D. (2008). Essentials of Entrepreneurship and Small Business Management. Upper Saddle River, New Jersey: Pearson Education Inc. 


\section{Copyrights}

Copyright for this article is retained by the author(s), with first publication rights granted to the journal.

This is an open-access article distributed under the terms and conditions of the Creative Commons Attribution license (http://creativecommons.org/licenses/by/4.0/). 